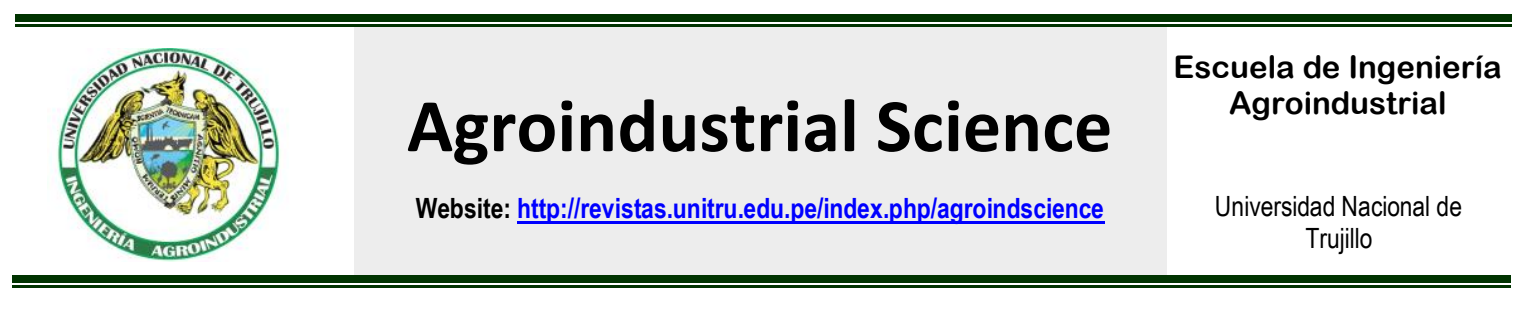

\title{
Study soil analysis in Alamo, Temapache and Veracruz, to generate doses of fertilization in orange
}

\author{
Análisis edafológico en Álamo Temapache, Veracruz, para generar dosis de fertilización \\ en naranja
}

\author{
A. Sastre-Decasa'; A. Flores-Trejo1; Gustavo Almaguer-Vargas 1,"; José Bernardo Hernández \\ Palomo1; M. Aguilar-Hernández² \\ 1 Departamento de Fitotecnia, Universidad Autónoma Chapingo. Km. 38.5, carretera México-Texcoco. Chapingo, Estado de México, C.P. \\ 56230. MÉXICO. \\ 2 Departamento de Horticultura. Facultad de Agronomía. Universidad Nacional Agraria La Molina. Lima-Perú. Av. La Universidad s/n. La \\ Molina. Lima, Perú.
}

\section{RESUMEN}

A nivel mundial los cítricos son el principal frutal cultivado, en México la producción de naranja es de gran importancia económica, los principales municipios productores del estado de Veracruz se encuentran Álamo, Papantla, Martínez de la Torre, Tihuatlán, Chicontepec y Temapache. Estas zonas, mantienen un rendimiento promedio bajo en comparación con otros países productores y un factor que puede mejorar los rendimientos es la óptima fertilización la cual tiene que ser respaldada con análisis de suelos para poder definir una dosis. Se realizaron 646 muestreos de suelo a una profundidad de $30 \mathrm{~cm}$, en el municipio de Temapache, Veracruz, mediante un muestreo aleatorio simple, el tamaño de la muestra se adaptó a las condiciones de cada comunidad. Los análisis fueron enviados a dos laboratorios. Se evaluaron el pH, materia orgánica, nitrógeno, fósforo, potasio. Los resultados se analizaron con estadística no paramétrica mediante un análisis de frecuencias para lo que se plantearon diez rangos, se utilizó $\mathrm{R}$ stadistic package versión 64 3.2.0. El pH en más del $70 \%$ de los suelos fue alcalino, la concentración de materia orgánica solo en el $34.44 \%$ se encontró en condiciones adecuadas, los macroelementos se encuentran en condiciones óptimas a excepción del nitrógeno el cual se presentó en niveles bajos.

Palabras clave: nitrógeno; fósforo; potasio; dosis de fertilización.

\begin{abstract}
Worldwide Citrus is the main fruit grown in Mexico orange production is of great economic importance, the main producing municipalities orange state of Veracruz are Alamo, Papantla, Martinez de la Torre, Tihuatlán, Chicontepec and Temapache. These areas, maintain a low average yield compared with other producing countries and a factor that can improve performance is optimal fertilization which has to be backed up with soil analysis to define a dose. 646 soil samples at a depth of $30 \mathrm{~cm}$, in the municipality of Temapache, Veracruz, by random sampling, sample size was adapted to the conditions of each community were made. Analyses were sent to two laboratories. $\mathrm{pH}$, organic matter, nitrogen, phosphorous and potassium were evaluated. The results were analyzed with nonparametric statistical analysis using frequencies for what ten ranges were raised, all with $\mathrm{R}$ software. The $\mathrm{pH}$ by more than $70 \%$ of the soil was alkaline, the concentration of organic matter in only $34.44 \%$ was found under suitable conditions, the macroelements are in good condition except nitrogen which was presented at low levels.
\end{abstract}

Keywords: Nitrogen; Phosphorus; Potassium; Fertilization doses.

\section{Introduction}

Globally citrus fruits are the main cultivated fruit, with an area that exceeds 8.3 million hectares, above crops such as bananas, apple trees or vine, world production of citrus by 2015 was 123.8 million tons, corresponding $58 \%$ to oranges, $23 \%$ to mandarins, $12 \%$ to lemons and $7 \%$ to grapefruit
(FAOSTAT, 2015). In Mexico the production of orange is of great economic importance, only in 2014 produced $\$ 6,727,474.63$. Veracruz harvests more than $50 \%$ of the national orange surface (SIACON-SAGARPA, 2015). Among the main orange producing communities in the state of Veracruz are Álamo, Papantla, Martinez de la Torre, Tihuatlán, Chicontepec and Temapache. 
The latter is mainly engaged in citrus production with a total of $50,718.75$ ha, of which $43,371.50$ ha are grown with orange. (SIAP-SAGARPA, 2015). However, according to data from SIACONSAGARPA (2015), orange yield per hectare in Veracruz has remained the same for the last 30 years, unlike other producing countries such as the USA, which double yields, compared with Mexico (FAOSTAT, 2015). One of the main reasons why production in Veracruz per unit area is low is due to the poor management of plant nutrition (Maldonado et al., 2008). According to Curti et al. (2000), there are no experimental results that make it possible to specify the fertilizer doses and times of application, which consider the nutritional status and demand of the crop and the nutrient soil supply, which leads to the use of general fertilization doses that do not they consider the specific needs of the crop or the soil characteristics (Alpizar et al., 2006).

In order to improve plant nutrition, methodologies have been proposed to estimate the fertilizer dose, considering crop demand, soil supply and fertilizer efficiency. When the amount of nutrients supplied by the soil is lower than that demanded by the crop to reach a specific yield, fertilizer must be applied (Etchevers, 1987; Szucs, 1997). This methodology, called restitution, takes into account the amount of nutrients extracted by the plants to produce the fruit, foliage, stems and roots, which are values of importance to determine the amount of nutrients removed from the soil reserves and therefore both the amount of fertilizer to be supplied according to the quantity of fruit produced. Based on the above, the aim of this study was to generate fertilization doses and an analysis of the levels of $\mathrm{pH}$ and organic matter in the soil, for the orange tree cultivation in the Álamo Temapache Veracruz production area, through the soil analysis of the soil and its interpretation.

\section{Materials and methods Location}

The project was developed in different communities in the municipality of Álamo Temapache, Veracruz in the spring-summer 2013 cycle, as part of the project entitled "Promotion of innovation to improve citrus yield in the Huasteca Region of Veracruz and Hidalgo" Linked to Universidad Autónoma Chapingo and the Directorate of Agricultural Development of the Municipality of Álamo.

\section{Evaluated variables}

The following municipalities were sampled: Adalberto Tejeda, Álamo tortuga, Ampliación reforma, Buena vista, Buenos aires, Chapopote, Citlaltepec, Hermenegildo Galeana, Ilusión, Inde- pendencia, La camelia, La esperanza, La esperanza, La mata, La providencia, La reforma, Las cañas, Limonar, Llano grande, Loma larga, Lucio blanco, Macario Cortez, Monte chiquito, Ojival Santa María, Otatal, Paso del perro, Rancho nuevo, Raudal nuevo, Raya oscura, Rodríguez clara, Tamatoco, Toaco, Tumbadero, Tumbadero del águila y Vara alta. Each of the producers who trained five ZIGZAG samples at $30 \mathrm{~cm}^{-1}$ depths in each farm was previously trained. The samples were mixed to generate a compound and take a $\mathrm{kg}^{-1}$ that was sent to laboratories Nutre Plantas and CEDEFRUT located in Texcoco de Mora state of Mexico and Tlapacoyan Veracruz, respectively.

The variables that were evaluated were: $\mathrm{pH}$ which was measured with a potentiometer in a 1: 2 soilwater ratio; organic matter (Walkley and Black, 1934); Nitrogen by kjeldahl method (Hesse, 1971); phosphorus by the method of Olsen (1954); potassium by the method of Bray and Kurtz (1945).

\section{Analysis of the data}

Sampling was simple randomized and the sample size was defined based on the conditions of each community ( $n=10$ to 30 ). The results obtained from each soil sampling were represented by an analysis of the distribution of frequencies and in this way to know the number of times a random variable was presented, a value of 10 ranks was taken to classify the results, $R$ software (version 64 3.2.0). In order to elaborate a nutritional diagnosis, Etchevers (1987) proposed the following formula to generate a fertilization dose: Fertilizer dose $=f$ (nutrient demand per crop (A) - availability of nutrients in the soil (B)/fertilizer efficiency (C)). The nutritional demand to calculate the fertilization dose was proposed by Maldonado et al. (2008), where they mention that for each ton of fruit produced, $1.86 \mathrm{~kg}^{-1}$ of $\mathrm{N}$ are extracted y $0.17 \mathrm{~kg}^{-1}$ of $P ; 2.25 \mathrm{~kg}^{-1} \mathrm{~K}$.

\section{Results and discussion \\ $\mathrm{pH}$}

The $\mathrm{pH}$ fluctuated in the different samples analyzed, in communities such as the Ojital Santa Maria values of 4.64 were obtained in contrast to the Tamatoco, which was found to be $\mathrm{pH} 8.36$. The frequency analysis performed on this variable showed that $70.12 \%$ of the total soil is between 7.03 -7.43 (Figure 1A), based on the official Mexican norm NOM-021-RECNAT-2000, which establishes the specifications of fertility, salinity, soil classifycation, are in a moderately alkaline classification, with this same reference we found that $1.54 \%$ of total poplar soils are acidic, $8.51 \%$ are moderately acidic, $19.65 \%$ neutral, $70.12 \%$ moderately alkaline and $0.15 \%$ to alkaline soils. 

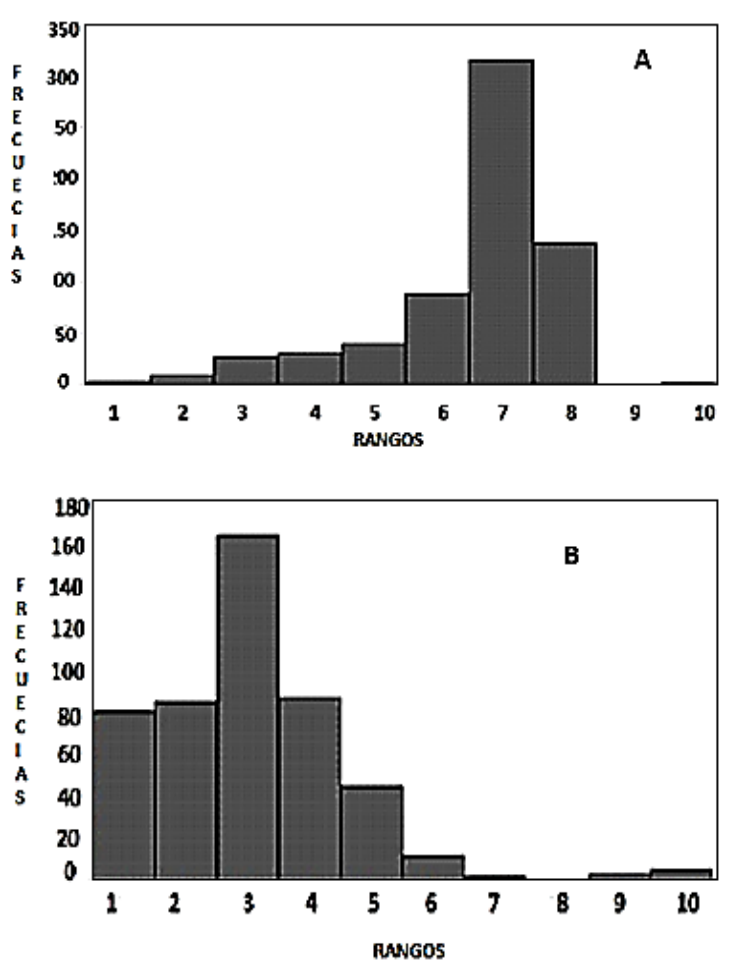

Figure 1. Frequencies of $\mathrm{pH}$ and organic matter (mg kg1) in ten ranges, $\mathrm{pH}(1=4.635-5.035,2=5.035-5.435,3=$ $5.435-5.835,4=5.835-6.235,5=6.235-6.635,6=6.635-$ $7.035,7=7.035-7.435,8=7.435-7.835,9=7.835-$ $8.235,10=8.235-8.635)$, organic matter $(1=0.245$ $1.145,2=1145-2.45,3=2.045-2.945,4=2.945-3.845$, $5=3.845-4.745,6=4.745-5.645,7=5.45-6.546,8=$ $6.545-7.445,9=7.445-8.345,10=8.345-9.245)$.

On the one hand, these results contrast with those obtained by Bautista et al. (1998) in their study for the classification of soils for productive purposes in Córdova, Veracruz, where they found that the $\mathrm{pH}$ was $80 \%$ acid and $20 \%$ neutral in the twenty-five soil samples made to nine communities. On the other hand, Cheng et al. (2016) in conducting a study to evaluate the quality of soils for orange production in China, found a wide variation in $\mathrm{pH}$ ranging from 3.75 to 8.23 , with acidest soils. Citrus fruits develop well in a $\mathrm{pH}$ range from 4 to 9 , however the optimal $\mathrm{pH}$ is between 5.5-7 (Molina, 2000). It is probable that the results are due to the fertilization applied in the zone, Liebig et al. (2002) mention that the application of fertilizers contributes to the decrease or increase of $\mathrm{pH}$ in the soil, this effect depending on the damping capacity of the same.

\section{Organic material}

Organic matter $(\mathrm{OM})$ is an active fraction of the soil its importance is vital in the productivity and sustainability of agricultural systems (Carter, 2002). The results obtained for this variable presented a wide fluctuation, values in communities such as "La Mata" and "Camelia" obtained values of $0.25 \%$ and in "Otatal" and "Vara Alta" values above $8 \%$. The frequency analysis performed with 10 classes found that the range with the highest number of samples is $2.045-2$. $945 \%$, with a total of $34.44 \%$ of the samples corresponding to soils with an average $\mathrm{MO}$ content (Figure 1B). Based on what was proposed by NOM-021-RECNAT-2000, 5.63\% were very poor soils, $6.26 \%$ poor soils, $15.44 \%$ moderately poor soils, $20.04 \%$ soils, $23.59 \%$ moderately rich soils, $17.32 \%$ rich soils and $11.69 \%$ soils rich in OM. Cheng et al. (2016) found that most of the orange crop is grown under conditions of low organic matter with contents ranging from 5.46 to $12.7 \mathrm{~g} \mathrm{~kg}^{-1}$ as in the case of Álamo Temapache, Veracruz. The wide variability in the results is supported by SAGARPA (2012) in a study of delimitation and integration of a National Network of Agro-technological Observatories (OATs), supported by ninety samples by producing areas of Veracruz, found that the average content of organic matter reaches more than $3 \%$ considered as medium, but with wide variability and very rich sites that exceed $5 \%$ and very poor sites with $0.7 \%$. Contains low amounts of organic matter, so increasing the percentage of organic matter by incorporating organic residues would help improve physical-mechanical conditions (Zhang et al., 2002). The results can be attributed to the management given to the soil for the production of orange, Álvarez (2001) and Lavado (2006), mention that the level of organic matter is dependent on the climate, soil and its management (tillage, rotations, fertilization) and the intensification of agricultural activity produces deterioration in OM levels.

\section{Nitrogen phosphorus and potassium}

The statistical frequency analysis indicated that $38.69 \%$ of the samples were found in a range of $2.095-12.095 \mathrm{mg} \mathrm{kg}^{-1}$ and $46,36 \%$ in 12.095-22.095 $\mathrm{mg} \mathrm{kg}^{-1}$ (Figure 2A).

These results indicate that $74.30 \%$ of the soils present low nitrogen content (NOM-021-RECNAT2000; Hardy et al., 2012).

Cruz et al. (2015) when assessing soil nitrogen dynamics in "La Mancha" Veracruz, found low element levels in all soil samples, with values ranging from 0.17 to $0.39 \mathrm{mg} \mathrm{kg}^{-1}$. These results may be due to the fact that nitrogen is a vital element in agricultural production and because the large amount required is the element that is found to be lesser in most soils (Echeverría and Sainz Rozas, 2005). Likewise, the levels of organic matter are low, which directly influences the nitrogen content of the soil (Echeverría and Sainz, 2007). 
Phosphorus deficiencies limit crop production and is one of the major global problems in soil fertility (Rashid et al., 2005). Phosphorus was an element that behaved similarly in most samples, the statistical range raised $0.445-19.445 \mathrm{mg} \mathrm{kg}^{-1}$ was the one that obtained $96.9 \%$ of the values (Figure 1B) and according to Hardy et al. (2012) and NOM-021-RECNAT-2000 correspond to soils with a mean element content. These results may be due to phosphorus soil precipitation or fertilization with elements such as iron or calcium (Khiari et al., 2005). The potassium evaluated in the samples presented little fluctuation, the range that obtained the highest number of values was 60-203 $\mathrm{mg} \mathrm{kg}^{-1}$ which represents $71.82 \%$ of the total of the samples, based on the NOM-021- RECNAT2000 , potassium levels are high. These results coincide with those found by Geissert and Ibañez (2008) in their studies to evaluate the edaphic quality and nutrient availability in agricultural soils of the central zone of Veracruz, where the seven samples evaluated had potassium values that fluctuated between the $50.74,136.85,163.8$, $218.96,222.87,238.51-492 \mathrm{mg} \mathrm{kg}^{-1}$ indicating that more than $70 \%$ of the samples are under optimum potassium conditions. The results can be attributed to that in a large part of the soils, a high concentration of potassium can be observed in the first $30 \mathrm{~cm}^{-1}$ (Brito and Rolim, 2005). However, citrus fruits remove a large amount of potassium, mainly fruits, is an element that is required in greater quantity after nitrogen (Molina, 2000), so it is necessary to take it into account in fertilization.

\section{Dose of fertilization}

The nutritional requirement of the crop was calculated by considering the extraction per ton of fruit harvested, with an expected yield of $20 \mathrm{t} \cdot \mathrm{ha}^{-1}$, the plant's investment in organ generation and maintenance, and the efficiency of fertilizers, so that, under the concept of restitution, an optimum fertilization of $\mathrm{N}, \mathrm{P} 2 \mathrm{O} 5, \mathrm{~K} 2 \mathrm{O} \mathrm{kg} \cdot \mathrm{ha}^{-1}$ was defined (Table 1).
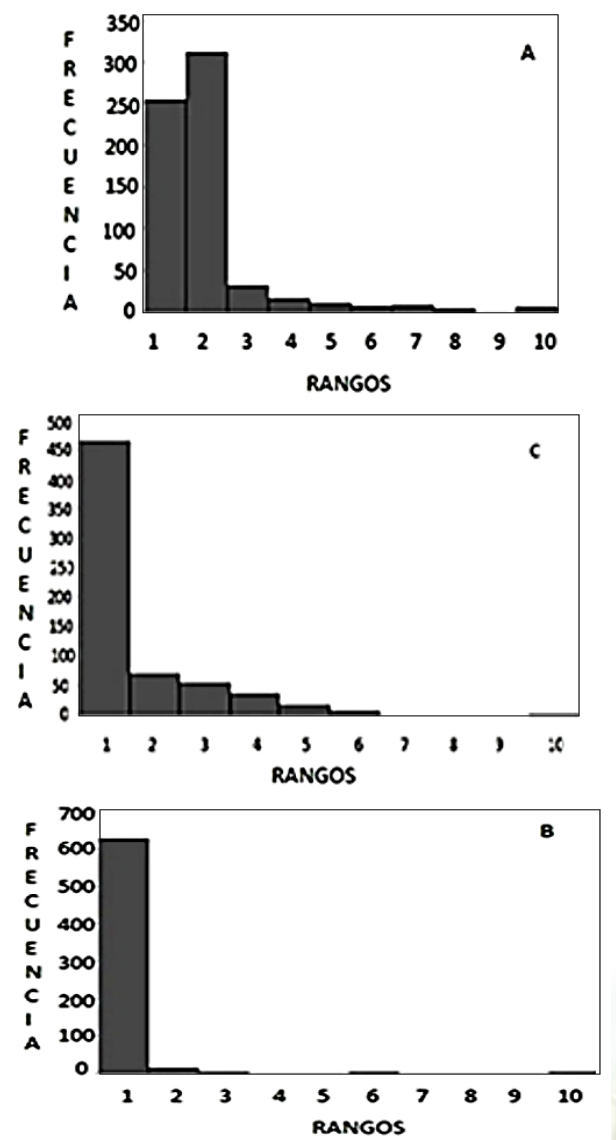

Figure 2. Frequencies of Nitrogen $\left(\mathrm{mg}^{\mathrm{k}} \mathrm{kg}^{-1}\right)(\mathrm{A})$, Phosphorus (mg. $\left.\mathrm{kg}^{-1}\right)(B)$ and Potassium $\left(\mathrm{mg}^{\mathrm{kg}} \mathrm{kg}^{-1}\right)(\mathrm{C})$ in ten ranges, nitrogen $(1=2.095-12.095,2=12.095$ $22.095,3=22.095-32.095,4=32.095-42.095,5=$ $42.095-52.095,6=52.095-62.095,7=62.095-72.095,8$ $=72.095-82.095,9=82.095-92.095,10=92.095-$ 102.095) phosphorus $(1=0.445-19.445,2=19.445$ $38.445,3=38.445-57.445,4=57.445-76.445,5=$ $76.445-95.445,6=95.445-114.445, \quad 7=114.445-$ $133.445,8=133.445-152.445,9=152.445-171.445,10$ $=173.445-190.445)$, potassium $(1=60-203,2=203-346$, $3=346-389,4=489-632,5=632-775,6=775-918,7=$ $918-1061,8=1061-1204,9=1204-1347,10=1347-$ 1490).

Table 1

Doses of fertilization by rank to produce 20 tons of fruit per hectare

\begin{tabular}{|c|c|c|c|c|c|c|c|c|c|c|}
\hline \multirow[b]{2}{*}{ Rank } & \multicolumn{4}{|c|}{ Nitrogen } & \multicolumn{3}{|c|}{ Match } & \multicolumn{3}{|c|}{ Potassium } \\
\hline & Dose & Rank & $\mathrm{mg} \mathrm{kg}^{-1}$ & Dose & Rank & $\mathrm{mg} \mathrm{kg}^{-1}$ & Dose & Rank & $\mathrm{mg} \mathrm{kg}^{-1}$ & Dose \\
\hline 2.095 & 47.4528 & 2 & $12.095-22.095$ & 0 & 1 & $0.445-19.445$ & 0 & 1 & $60-203$ & 0 \\
\hline 3.095 & 41.6928 & 3 & $22.095-32.095$ & 0 & 2 & $19.445-38.445$ & 0 & 2 & $203-346$ & 0 \\
\hline 4.095 & 35.9328 & 4 & $32.095-42.095$ & 0 & 3 & $38.445-57.445$ & 0 & 3 & $346-389$ & 0 \\
\hline 5.095 & 30.1728 & 5 & $42.095-52.095$ & 0 & 4 & $57.445-76.445$ & 0 & 4 & $489-632$ & 0 \\
\hline 6.095 & 24.4128 & 6 & $52.095-62.095$ & 0 & 5 & $76.445-95.445$ & 0 & 5 & $632-775$ & 0 \\
\hline 7.095 & 18.6528 & 7 & $62.095-72.095$ & 0 & 6 & $95.445-114.445$ & 0 & 6 & $775-918$ & 0 \\
\hline 8.095 & 12.8928 & 8 & $72.095-82.095$ & 0 & 7 & $114.445-133.445$ & 0 & 7 & $918-1061$ & 0 \\
\hline 9.095 & 7.1328 & 9 & $82.095-92.095$ & 0 & 8 & $133.445-152.445$ & 0 & 8 & $1061-1204$ & 0 \\
\hline 10.095 & 1.3728 & 10 & $92.095-102.095$ & 0 & 9 & $152.445-171.445$ & 0 & 9 & $1204-1347$ & 0 \\
\hline 11.095 & 0 & & & & 10 & $173.445-190.445$ & 0 & 10 & $1347-1490$ & 0 \\
\hline
\end{tabular}

${ }^{* *}$ Apparent density $=1.2$, Fertilization efficiency: nitrogen $60 \%$, phosphorus $20 \%$ and potassium $60 \%$. 
It can be observed that in general, the fertilization dose is only circled by nitrogen. Maldonado et al. (2008), found that the substitution method can help find the best fertilizer dose, which reduces economic losses and pollution. In their study in 'Persian' lemon, they observed that the regional fertilization recommendation was 828 grams per nitrogen plant per tree; when applying the restitution method, the fertilization dose found was less than half ( $828 \mathrm{~g}$ to $310 \mathrm{~g}$ per tree of $\mathrm{N}$ ), and a significant increase in yield was obtained, implying a better efficiency of fruit produced by applied nitrogen.

Alva et al. (2006) significantly improved the efficiency of $\mathrm{N}$ utilization in 'Hamlin' orange, since it only used $2.2-2.3 \mathrm{~kg}$ of $\mathrm{N}$ to produce a $\mathrm{Mg}$ of fruit, through an efficient use of irrigation and the management of the fertilizer. Koo et al. (1984) found that $4.4 \mathrm{~kg}$ of $\mathrm{N}$ were required to produce $1 \mathrm{Mg}$ of fruit. Maldonado (1999) found a ton of Mexican lime fruit containing $1.8 \mathrm{~kg}$ of N.

The $\mathrm{pH}$ evaluated in the samples indicated that the majority are alkaline, the fertilization should be with superfostofato, anhydrous ammonia, or ammonium sulphate, monoammonium phosphate and diammonium phosphate, which have a higher acidity index than ammonium nitrate, anhydrous ammonia and urea (FAO, 1992).

\section{Conclusions}

The $\mathrm{pH}$ levels in the soils are mostly alkaline, results that are influenced by the type of fertilizers that are applied in the zone, reason why to lower to the optimum level is a necessary task. Organic matter in general is found in stable soil conditions, only $5.63 \%$ are very poor soils, $6.26 \%$ are poor soils and $15.44 \%$ are moderately poor soils. The levels of potassium and phosphorus fertilizers are in optimal conditions so the recommended doses did not include fertilization of these elements, although the nitrogen in the soils is low, therefore the recommended doses for the rank one which fluctuated from the 4 to $2 \mathrm{~kg} \mathrm{ha}^{-1}$ of nitrogen.

\section{References}

Alpízar, M.E; González, D.F.; Spaans, E.; Tabora, P. 2006. Plan dinámico de fertilización para escalopine verde (Cucurbita pepo). Tierra Tropical 2:39-47.

Alva, A.K.; Paramasivam, S.; Obreza, T.A. Schumann, A.W. 2006. Nitrogen best management practice for citrus tres I. Fruit yield, quality, and leaf nutritional status. Scientia Horticulturae 107: 233244.

Álvarez, R. 2001. Estimation of carbon losses by cultivation from soils of the Argentine Pampa using the Century Model. Soil Use and Management 17: 62-66

Bautista, Z.F.; Rivas, S.; Durán de Bazúa, H.C. 1998. Caracterización y clasificación de suelos con fines productivos en Córdoba, Veracruz, México. Investigaciones geográficas 36: 21-33.
Bray, R.H.; Kurtz, L.T. 1945. Determination of total, organic and available form of phosphorus in soil. Soil Science 59: 360-361.

Brito, F.L.; Rolim, M.M. 2005. Comportamento do efluente e do solo fertirrigado com vinhaça. Agropecuária Técnica 26: 60-67.

Carter, M.R. 2002. Soil quality for sustainable land management: Organic Matter and Aggregation Interactions That maintain Soil Function. Agronomy Journal 94: 38-47.

Cheng, J.; Ding, C.; Li, X.; Zhang, T.; Wang, X. 2016. Soil quality evaluation for navel orange production systems in central subtropical China. Soil and Tillage Research 155: 225-232.

Cruz, H.L.; Suárez, M.G.; Campos, C.A. 2015. Dinámica del carbono y nitrógeno del suelo en ecosistemas de la costa tropical seca, en la mancha (cicolma), Veracruz, México. Tropical and Subtropical Agroecosystems: 347-361.

Curti, D.S.; Loredo, A.X; Díaz Zorrilla, U.; Sandoval, A.R.; Hernández H.J. 2000. Tecnología para producir limón persa. INIFAP. CIRGOC. Campo Experimental Ixtacuaco. Libro Técnico 8. Veracruz, México.144 pp.

Echeverría, H.E.; Sainz, R.H. 2005. Nitrógeno. 69-95. In: Echeverría H. E. and Garcia F.O (eds.). Fertilidad de Suelos y Fertilización de Cultivos. Editorial INTA, Buenos Aires, Argentina.

Echeverría, H.E.; Rozas, H.S. 2007. Nitrógeno. En: Fertilidad de Suelos y Fertilización de Cultivos. H.E. Echeverría y F.O. García. Ediciones INTA, Buenos Aires, Argentina. 69-97 pp.

Etchevers, B.J. 1987. Diagnóstico visual. Centro de edafología. Colegio de Postgraduados. Chapingo, México.68-69 pp.

Etchevers, B.J. 2001. Manual de procedimientos analíticos para análisis de suelos y plantas del laboratorio de fertilidad de suelos. IRENAT. Colegio de Posgraduados. Sociedad Mexicana de la Ciencia del Suelo A.C

FAO. 1992. World Fertilizer Use Manual, 1992, IFA, París, 632 pp.

FAOSTAT, 2015. Food and agriculture organization of the United Nations. Observatorio de precios y mercados europeos

Geissert, D.; Ibañez A. 2008. Calidad y ambiente físico- químico de los suelos.In: Agro ecosistemas cafetaleros de Veracruz. Biodiversidad, manejo y conservación. Manson H. R. HernándezOrtiz V., Gallina. S., Mehltreter. Instituto de Ecología A.C, México $348 \mathrm{pp}$.

Hardy, H.: Tucker, M.R.; Kent, M.J.; Catherine, S.M. 2012. "Understanding the Soil Test Report", published by N.C. Department of Agriculture \& Consumer Services Agronomic Division. $6 \mathrm{p}$.

Hesse, P.R. 1971. Total nitrogen. The Kjeldahl process. A textbook of soil chemical analysis. Murray, Great Britain, $520 \mathrm{pp}$.

Khiari, L.; Parent, L.E. 2005. Phosphorus transformations in acid lighttextured soils treated with dry swine manure. Canadian Journal of Soil Science 85(1): 75-87.

Koo, R.C.J.; Anderson, C.A.; Stewart, I.; Tucker, D.P.H.; Calvert, D.V.; Wutscher, H.K. 1984. Recomnended fertilizers and nutritional sprays for citrus. Fla. Agric. Exp. Stn. Bull. 536 pp.

Lavado, R. 2006. La región Pampeana: Historia, características y uso de sus suelos. In: Materia Orgánica "Valor Agronómico y Dinámica en Suelos Pampeanos" (ed. R Álvarez). Editorial. Facultad de Agronomía, Universidad de Buenos Aires. 1-12 $p$

Liebig, M.A.; Varvel, G.E.; Doran, J.W.; Wienhold, B.J. 2002. Crop sequence and nitrogen fertilization effect on soil properties in the western corn belt. Soil Sci. Soc. Am. J. 66: 596-601.

Maldonado, T.R. 1999. El diagnóstico nutrimental en la producción de lima mexicana. Ed. Fundación Produce Michoacán y Universidad Autónoma Chapingo. México. $82 \mathrm{p}$.

Maldonado, T.R.; Almaguer, V.G.; Álvarez, M.E.; Robledo, S.E. 2008. Diagnóstico nutrimental y validación de dosis de Fertilización para limón persa. Terra Latinoamericana 26: 4.

Molina, E. 2000. Nutrición y fertilización de la naranja. Informaciones Agronómicas. №. 37.

Norma Oficial Mexicana. 2002.Especificaciones de fertilidad, salinidad y clasificación de suelos. Estudios, muestreo y análisis. NOM-021RECNAT-2000

Olsen, S.R.; Cole, C.V.; Watanabe, F.S.; Dean, L.A. 1954. Estimation of available phosphorus in soils by extraction with sodium bicarbonate. USDA 20 (1) 200253 Circ. 939

Rashid, A.: Awan, Z.I.; Ryan, J. 2005. Diagnosis of phosphorus deficiency in spring wheat by Plant Analysis: The Critical Concentration ranges proposed. Communications in Soil Science and Plant Analysis: 609-622. 
SIACON-SAGARPA. 2015. Sistema de información agropecuaria. SIACON, Secretaria de Agricultura, Ganadería, Desarrollo Rural, Pesca y Alimentación.

Szucs, H. 1997. Possibilities to meet nutritional requirements of fruit trees and environmental protection. Acta Hortic. 448: 433-436.

Walkley, A.; Black, I. 1934. An examination of the Degtjareff method and a proposed modification of the chromic matter and a proposed modification of the chromic acid titration method. Soil Sci. 34: 29$38 p$.

Zhang, H.; Hartge, K.H.; Ringe, H. 1997. Effectiveness of organic matter incorporation in reducing soil compactability. Soil Science Society American Journal 61(1): 239-245. 